\title{
The Production of the New Man Within the PKK
}

Également disponible en version française

\section{Olivier Grojean}

Translator. Adrian Morfee

\section{OpenEdition Journals}

\section{Electronic version}

URL: http://journals.openedition.org/ejts/4925

DOI: $10.4000 /$ ejts.4925

ISSN: $1773-0546$

\section{Publisher}

EJTS

\section{Electronic reference}

Olivier Grojean, «The Production of the New Man Within the PKK », European Journal of Turkish Studies [Online], Complete List, Online since 09 July 2014, connection on 19 February 2020. URL : http:// journals.openedition.org/ejts/4925 ; DOI : 10.4000/ejts.4925

This text was automatically generated on 19 February 2020.

(c) Some rights reserved / Creative Commons license 


\section{The Production of the New Man Within the PKK}

Également disponible en version française

Olivier Grojean

Translation : Adrian Morfee

\section{EDITOR'S NOTE}

Originally published as 'La production de l'Homme nouveau au sein du PKK', European Journal of Turkish Studies 8 (2008).

URL: http://ejts.revues.org/2753

\section{AUTHOR'S NOTE}

Many thanks to Adrian Morfee, Marc Aymes and Nicole Watts for their help in preparing for the English version of the text.

1 There is nothing new about the idea that socialism or nationalism might bring about a revolutionary regeneration of the human and social body, and it no doubt reaches back to the time of the French Revolution (Ozouf 1989: 116-157). ${ }^{1}$ After the First World War this idea became widespread in Europe, and was at least partially applied by fascist regimes and in the Soviet Union (Batard-Bonucci; Milza 2004; Pennetier; Pudal 2002). From the 1920s and especially early 1930s onwards, the Italian and Soviet models also acted as the inspiration for various tendencies within Turkish nationalism that were looking to create their own versions of the New Man (Aydın 2003; Irem 2002). Since then, and independently or not of these experiences, the number of political and religious movements and political regimes to have been influenced by theories about the regeneration of man is so large that it would be pointless to seek to list them all. 
2 Frequently it has been states that have constructed these theories and put them into practice, and so they tend to have been analysed in terms of totalitarianism and its official ideologies. Research has concentrated on the state policies of totalitarian regimes, even though the idea of the regeneration of man through revolution is frequently present in numerous political parties and movements not (yet) in power, and sometimes even put into practice by them. ${ }^{2}$ The upshot has been a certain insistence on the myth of the New Man and on the associated ideas, beliefs, rites, and aesthetics, within a specifically 'authoritarian' context, and this arguably at the expense of studying small-scale measures seeking to bring about concrete transformations at the level of the individual. ${ }^{3}$

The perspective adopted here seeks to make up for this oversight. The analysis has been deliberately restricted to a single movement so as to bring the relationship between theory and practice into sharper focus, and especially to more fully assess the concrete effects of a single specific doctrine and how activists apply it. One of the main contributions of the sociology of collective action is to have shown that it is not possible to infer a movement's repertoire of action from the ideology it develops, ${ }^{4}$ but this does not hold good for internal activist practices (roles, value-attitude systems, means of personal involvement, and so on) which, as part of a radical organisation devising a project for a counter-society, are less dependent on the external environment. ${ }^{5}$ By studying the example of the relationship between the belief system and activist practice in the Kurdistan Workers' Party (PKK), ${ }^{6}$ this article seeks to demonstrate how a specific theory of the New Man translated into practice for many of the organisation's activists, to the point where over 200 of them have voluntarily sacrificed themselves to their party's cause (by self-immolation and by carrying out suicide attacks).

This article, without seeking to account for such extreme instances ${ }^{7}$ or view the PKK via preconceived categories, ${ }^{8}$ starts by analysing the discourse produced by the main Kurdish movement organisation in Turkey so as to better understand how a certain imaginative construction of the New Man emerged. It then draws on written works and journals kept by former combatants, activists, and party sympathisers to study the disciplinary mechanisms used to put this theory into practice in the various branches of the organisation. The results of an interview study are then presented, conducted with forty-odd PKK activists and sympathisers in Europe, some still actively involved, others not, so as to try to evaluate the effectiveness of this 'coercive architecture' (Grojean; Küçük 2006: 68). ${ }^{9}$ Without going into their personal trajectories in detail, the aim is both to identify certain factors that can help explain why they seek to model their lives on an ideal put forward by the PKK leader, and to analyse how individuals handle the dissatisfactions and disappointments attendant upon their involvement in the institution. ${ }^{10}$

\section{The theory of the New Man}

\section{Communism, nationalism, and the New Man}

5 The PKK, a participant in the Kurdish movement in the Middle East, very clearly positions itself within a nationalist project. In opposition to Turkish nationalism, which held that Anatolia is the cradle of Turkishness and affirms that Kurds are 'mountain Turks' and the Kurdish language in fact a sub-language of Turkish, Kurdist groups and 
the PKK put forward a nationalism literally constructed as its 'mirror image,' with its own symbols (the Kurdistan flag - even if the PKK has its own 'national' flag -, geographical map, and so on, cf. O'Shea 1994), its own myths (Newroz, celebrating the revolt of Kawa the blacksmith against the tyrant Dahhak; the Medes, from whom the Kurds declare they are descended), ${ }^{11}$ its own heroes (the leaders of the 1930s revolts, and leaders of the PKK and Öcalan), and its own traitors and martyrs (Strohmeier 2003).

And like all nationalisms, this one comes with its own unique historiography, seeing the Kurdish revolts as part of the age-old repression of the Kurdish people - whereas they are in fact primarily a revolt against the state qua state - with the PKK (at least) affirming that Turkish, Arab, and Persian colonisation amount to a deliberate project to alienate the Kurdish nation. The social, linguistic, and religious fragmentation to be found in Kurdish-majority regions in Turkey means that the populations need to be unified around a feeling of belonging, a feeling of Kurdishness, that is to say an entity larger than tribe, religion, or language.

But whilst nationalism provides a perspective on the past and a goal for the future, it is not particularly concerned with the present and so necessarily runs the risk of being seen as too particular where what is needed to mobilise people is a certain universalism, an economic model to be put into practice, and a societal project (Bozarslan 1997: 115-116). And so like numerous other political organisations in the 1960s and 1970s in the Middle East, the PKK therefore adopted Marxism-Leninism as a 'borrowed doctrine.' But whilst for some parties this ideology acted primarily as a veneer that soon flaked off (such as for the KDP in Iraq), for Öcalan's party it acted as a stock of ideas, means, and projects, and thus exerted a strong influence over its combat.

8 The PKK's first text published in 1978, The Path of the Revolution in Kurdistan - Manifesto (Kurdistan Devrimin Yolu - Manifesto) resembles the programme of any national liberation movement drawing on Marxist arguments. The first part of the work (on the history of class society and colonialism) frequently refers to the 'materialist conception of history,' 'scientific socialism,' 'class struggle,' and 'surplus value,' for instance (Özcan, 2006: 100), whilst the second and third parts deal with Kurdish society, the enslavement of the Medes, and the colonisation of Kurds in terms of 'the exploitation of Kurdistan' by the 'Turkish bourgeoisie' and its 'feudal collaborators' (PKK 1986). ${ }^{12}$

These ideological references are significant for they influenced the direction the PKK struggle took in the 1980s and 1990s. But alone they do not suffice to explain the emergence within the party of a theory of the New Man. It is true that these references perhaps make it easier to sacralise the party leader than others might (thanks to the theory of the avant-garde), and to legitimate the current combat (by mobilising historical references and supposedly scientific concepts). But all the Kurdist parties in Turkey in the late 1970s had a very similar ideological discourse.

\section{The New Man and counter-society}

10 One way a group can differentiate itself - other than highlighting frequently obscure theoretical differences with other political currents - is to focus more on the core of the organisation, without paying much heed to how discourse is received outside the organisation, especially since in the late 1970s the vast majority of the population of south-east Turkey was not at all receptive to Marxist vocabulary. Frontiers of group 
belonging are delineated by imposing specific practices (relating to dress, hair, language, etc.) reinforcing collective cohesion and homogeneity. For the PKK, the heightened commitment of its activists made up for its weak resources (Dorronsoro; Grojean 2004):13 before the 1980 coup, it was the only truly clandestine organisation, that is to say structured like a military body into separate units, within which activists were functioning as 'professional revolutionaries' with full-time involvement in the struggle.

11 But whilst its clandestine status and concomitant strict rules no doubt made it possible for part of the PKK to survive in exile, this was not enough to prevent denunciations, betrayals, and infiltrations resulting in the arrest of hundreds of party members after 12 September. These setbacks were compounded by internal opposition and the setting up of Korucu militia (village guards who were paid and armed by the state) in 1985. For the party leadership, the only way of preventing internal dissent and betrayals was supervision and training. In the mid-1980s, the various components of the ERNK (Eniya Rizgarîya Netewayi Kurdistan, National Liberation Front of Kurdistan) set up to supervise and train the population, the founding of the Akademîya Mahsum Korkmaz in charge of the political and military education of combatants, and the introduction of obligatory military service and a penal system within the organisation, may all be interpreted as attempts to curb these centripetal tendencies (Çelik 2002: 60, 109). The PKK's Marxism and nationalism were subsequently adapted to these issues.

The first work to refer to the 'personality' of the Kurds came out in 1983 (Öcalan 1983), but the question of the individual only became central to Öcalan's writings in the following years when guerrilla training started in Lebanon. The notions of ' humanisation,' 'socialisation,' 'individual emancipation' (özgürleşme), 'self,' and ' liberated personality' progressively replaced the classical Marxist notions of 'class struggle' and 'historical materialism' (Öcalan 1986: 17, quoted in Özcan 2006: 109). 'Selfproduction,' that is to say the generation of a virtuous personality liberated from both Turkish alienation and alienation by traditional social structures and so worthy of the guide's trust, progressively became the only path offered to activists in the Çözümlemeler (Analyses), lectures given by Öcalan himself at the Academy: ${ }^{14}$

Our revolution, initially ideological, political, and military in nature, is increasingly becoming a social one. That transforms peoples' lives a lot more and so produces major results and strong reactions. This is an uprising against the old social order against the world of socialisation, relations, feelings, and impulses developed by the enemy. We are seeking to destroy this world (Öcalan 1997a: 35).

This shift in intellectual direction is of course related to the 'New Man' that the Soviet Communist Party wished to create, but it also needs to be seen in relationship with Kurdish historiography in the 1920s and 1930s. Kurdish nationalism - working against Turkish historiography which was promoted to the status of a state ideology after 1923 (see Copeaux 1997) - bears the imprint of social Darwinism and racial anthropology, and draws on the repression of numerous Kurdish revolts in the 1920s and 1930s. It is based on the idea of a struggle for the survival of the race and on the premise of a biological nation made up of individual cells - some healthy, others not - building up an alternative narrative by reworking the themes of unity and of the enemy within found in Turkish historiography (Bozarslan 2001). ${ }^{15}$ 


\section{The characteristics of the New Man}

14 Platonic philosophy of the subject or that of Touraine, as Ali Kemal Özcan rather
complacently suggests (Özcan 2006: 111):

The new man does not drink, does not gamble, never thinks of his own personal pleasure or comfort, and there is nothing feminine about him, and those who [in the past] indulged in such activities will, sharp as a knife, cut out all these habits as soon as he or she is among new men. The new man's philosophy and morality, the way he sits and stands, his style, ego, attitude and reactions [tepki] are his and his alone. The basis of all these things is his love for the revolution, freedom, country, and socialism, a love that is as solid as a rock. Applying scientific socialism to the reality of our country creates the new man. (Üçlü 1996: 21).

The Kurds thus need to be 'socially' educated and persuaded 'that they are slaves and need to be liberated' (Bozarslan 1997: 106). This applies to activists more than to anyone else, for they always run the risk of betraying the cause through lack of faith or discipline:

'The enemy plays with youth and its impulses. And it is ready to fight, ready for every danger and all your difficulties. The enemy plays with you. And so you have to be very careful. If you accept to say: "I am in good faith, and will adhere to the principles of the party and of a free life", then you will stand out for your good behaviour. Otherwise you are a danger, with your behaviour serving one knows not who. That is why political, military, and ideological training are insufficient, and what is needed is social education. When you hear people speak of social education do not think that you are meant to ask yourself whether you are "a well-behaved daughter or a good son." Such people are perhaps the least educated. Social education is in fact about taking steps against the influence of the enemy, and taking steps against outmoded social debris [...] and, most importantly, about giving concrete form within one's personality to the aims of the revolution - be they political, social, economic, or cultural - in short, what a healthy society needs. That is what social education is. You will progress in this area until you become an activist with a social objective. Being an activist is not enough. You need to be a social activist. What is a social activist? A social activist is someone who has an absolutely revolutionary character in his or her everyday relations with others.' (Öcalan 1997b: 42)

But what counts, even more than being faithful to the party's principles, is being faithful to Öcalan in person, on which the cause and a better life are both founded. It is by following his example - but without imitating him - that one can become a good activist and a New Man worthy of the name:

'Many of you resemble the dead. Life does not touch you. Your passion and joy are very weak, your awareness insufficient, your hearts closed. You have strayed from sensitivity and responsibility, and turned towards an interest that is not the necessary interest. We are different. The problem is bringing you up to the same level [as ours]. It is possible, and you have to believe in it. All our example can do is encourage you. You should not try to imitate our personality, but set out on the path of your own development. You do not need to imitate. There are impressive, enlightened ways to take you where you need to go.' (Öcalan 1997a: 35)

And above and beyond the disciplined way of living evidenced here, the main instrument for transforming Man is 'holy' or 'sacred' war. This mystique of violence is based on 'the liberating step whereby the colonised, adopting violent means against an all-powerful order and master, effects a radical break with the inferior position 
previously assumed. He thereby rediscovers his dignity and identity which had been obliterated by colonialism' (Chaliand 1991: 23). Violence is promoted to the status of fountainhead 'of each society, as well as of each of its cells' (quoted in Bozarslan 1997: 219). By inverting the process of traumatisation and stigma, it creates a new and better man (Sartre 1991: 51, 54), and is even more effective insofar as this 'war has [also] been waged within, within the party and within the people. ${ }^{16}$

If we add to this the fact that the interest accorded to the issue of women - which also emerged in 1986-1987 after the Central Committee sidelined Öcalan's wife, Kesire Ylldirım - is part of a desire to control gender and sexual relations (Grojean 2008: 504-513; Grojean 2013a) ${ }_{1}^{17}$ it becomes clearer to just what extent the theory of the New Man is different from an ideology in the strict sense of the word, and is in fact closer to an ideal way of life requiring self-analysis and self-development, a political imaginative construction seeking to bring about a radical transformation of the habitus of committed individuals in the here and now. ${ }^{18}$ For various surveillance, control, and repression measures have been set up within the branches of the institution so as to ensure these principles are correctly implemented.

\section{Measures to educate, control, and repress}

19 Like other institutions, the PKK sees itself primarily as a teaching and even an educational organisation insofar as its officials and 'Leadership' (Önderlik, the name given to Öcalan) are permanently working to bring practice into line with discourse. Whilst it is certainly the case that 'any institution [...] only takes on concrete form in the commitment [of its members],' the idea that 'the effect members have on practices does more to alter them than instructions laid down by leaders' (Lagroye 2006: 50, 65) or to put the same idea differently, discourse and ideas only serve to rationalise, justify, and lend legitimacy to pre-existing practices - needs here to be nuanced. Activist practices within the PKK are heavily dependent upon Öcalan's Çözümlemeler, which, though to some extent tending to rationalise the daily constraints of war and the PKK's clandestine status, also initiate new ways of acting and thinking. The aim truly is to create a miniature counter-society to serve as a model for Kurdish society and perhaps even influence the whole world.

\section{Training in the Mahsum Korkmaz Academy}

This undertaking is furthered by the Mahsum Korkmaz Academy, which was founded in Helve in the Bakaa valley in Lebanon in 1986, before moving to Syria in 1993 near Damas, and then to Iraq's Kurdish region in 1998 where it still is. Between 1986 and 1998, it is believed that over 10,000 party activists and commanders attended this 'school' for training sessions lasting about three months or some longer re-education programmes lasting several years. But despite this large figure it would be wrong to think that all guerrillas trained in this Academy. From the early 1990s onwards most young recruits were trained in their combat unit, especially during winter when there are fewer clashes with the Turkish army. In 1991 training included a political aspect lasting two months and a military part lasting one month (Arbeitskreis Internationalismus Bonn et al. 1991: 7), attended by a 'platform' of between 100 and 250 activists. In the 1990s, on arriving new members take an oath of loyalty to the party, 
martyrs, leader, and cause, and are given a new first name (frequently a Kurdish one), intended both to prevent any repression and symbolise their desire and commitment to starting a new life (Flach 2003: 22).

'Trainees' often had busy days (10 to 12 hours of classes) leaving little free time. They rose at six and assembled for roll call to salute and proclaim the maxim 'ya serfketin, ya naman' (freedom or death). Sometimes there was an hour's sport before breakfast at seven, and lessons started at eight and run through to lunchtime. Most of them were in Turkish, even though there were sometimes parallel sessions in Kurdish. Classes started again at $2 \mathrm{pm}$ and went through to the evening meal at $8 \mathrm{pm}$. The evening was either taken up by other training sessions, or else free time (football - often with Öcalan - volley-ball, and Kurdish dances on special occasions). This typical day was subject to considerable variation, when for instance there were leadership elections, a special address by Öcalan, talks - on resistance in prison after the 12 September for instance or else an exercise simulating an attack by the Turkish armed forces (Arbeitskreis Internationalismus Bonn et al. 1991: 8-11).

Whilst the subjects covered in class were varied, ${ }^{19}$ trainees were repeatedly reminded that ' $90 \%$ of the combat is against your old personality, the enemy within, and only $10 \%$ against the external enemy' (Flach 2003: 22). Until 1998 Abdullah Öcalan himself taught his Çözümlemeler every two or three days, and his lectures generally lasted between four and seven hours, given without notes and without any breaks. Most of the time what he had to say was based on concrete examples from his own life, and especially his youth, intended to reveal how to foster a new personality (Solina 1997: 327). He would then criticise activists whose PKK personality was insufficiently developed (PKKleşme), before questioning them so as to get them to adopt a clear position.

The trainees then started their self-criticism just after Öcalan's lesson, and often in his presence. They were asked what they lesson they had drawn from Öcalan's lecture (and if they were not willing to answer could be deemed to be hiding something), what they took away from it about their own behaviour, and how they intended to improve. This mainly involved looking for what in their 'former life' was still operative and blocking the emergence of a new personality. Other activists who knew the person who had just presented their self-criticism then spoke to confirm or invalidate their self-analysis, using categories such as 'feudal,' 'petit-bourgeois,' 'career-oriented,' 'patriarchal,' '12 September,' or 'convict. ${ }^{\prime 20}$ It was generally very severely frowned upon to react in an 'emotional and ill-thought out way' to this criticism, and the reasons underlying this behaviour were then immediately discussed (Solina 1997: 333). Displaying any opposition to the idea of male-female relations set out by the trainer could cause a real scandal and result in the lesson being suspended (Çürükkaya 1997: 89). Öcalan or the trainer present would then assess progress made by the activist, highlighting both areas of success and where further effort was needed.

\section{Criticism, self-criticism, and behavioural compliance}

24 This specific phase of self-criticism and criticism spread to other areas of the Academy's social life, during elections to camp leadership, for instance, (the commanders were criticised by Öcalan, and then had to conduct their own selfcriticism), or when problems occurred within a unit (criticism and self-criticism by a small group). But whilst criticism of the commanders and activists was deemed 
necessary, any criticism of Abdullah Öcalan was still impossible. Self-criticism thus rapidly became the main instrument for normalising discourse, as of 1986 and the $3^{\text {rd }}$ Party Congress. As Annie Kriegel suggests in relation to communist systems, 'selfcriticism has the potential to be a healthy form of critical analysis of oneself [...], but in practice it is a confession where what the audience expects to hear is not the analysis of some error but the revelation of a fault of some sort, and so it generally produces humiliation' (Kriegel 1972: 92). The confession is thus a mark of submission, and the proclamations of allegiance and love that go with it - where the form is far more important than the content - are meant to act as a guarantee of the activist's adhesion to the party and its leader.

But it would be incorrect to think that the Leadership stops at words and bases its judgement of activists' progress purely on what they say. The Çözümlemeler need to be applied, and this should result in the activists renouncing both their former life (they are obliged to cut ties with their family, spouse, children, friends, and so on) and certain attitudes and habits. They are for instance not allowed to cross their legs (only Öcalan is allowed to do that), to make hand gestures when speaking (Öcalan's privilege), or to sit before being instructed to do so (attitudes typical of the 'enemy's style,' cf. Çürükkaya 1997: 80, 83). Drinking alcohol, smoking tobacco, and having sexual or even purely platonic relationships are also forbidden, as 'recommended' by Öcalan in his talks. ${ }^{21}$ If it is born in mind that the Academy is also a military institution where everyone must stand up straight and be dressed in the same way without any distinctive signs (which would be evidence of an individualistic personality influenced by consumer society), it becomes clear that this physical and linguistic discipline partakes in a genuine desire to transform the habitus of the individuals, and thus complies with the theory of the New Man.

Various means are in place to regularly test the progress made by activists. At the end of training they write a self-critical report, which is often presented and debated in public. If their self-criticism is judged insufficient, they may be obliged to produce another report, further training may be imposed, or a trial be held. The Academy has its own tribunal in charge of judging deviant personalities, and those appearing before the tribunal are held apart in a special building prior to trial to reflect on their acts. ${ }^{22}$ If the assembly considers the 'culprit's' personality to be susceptible to improvement, then the judgment may be lenient, but it can also be very severe and even result in the death penalty if the person is found guilty of having had a relationship with a member of the opposite sex or of having betrayed the party's principles. Judgement is then either be followed by an execution or else commuted to a less severe sentence by Öcalan himself (Çürükkaya 1997: 106, 115, 118-119, 146, 159-170). Selim Çürükkaya states that over 50 people were executed between 1985 and $1992 .{ }^{23}$

\section{Generalisation of discipline to other branches of the institution}

The way the Mahsum Korkmaz Academy works is of course not necessarily an indication of how the PKK functions as a whole. The Academy is a strictly closed military institution where what activists do is controlled 24 hours a day, and where proximity to the 'Leadership' makes it possible to denounce and reprehend any slippage in behaviour. Nevertheless, the desire to homogenise the habitus is found in the other branches of the party too. The highly centralised structure of the 
organisation and Abdullah Öcalan's place within it ('Öcalan is nowhere, he is in the heart of every Kurd' commander Kanı Y1lmaz observed just after the PKK leader was captured), along with the use of certain modern means of communication, have made it possible to try to reproduce the educational system of the Akademîya Mahsum Korkmaz outside the Bekaa valley in Lebanon. Academy trainees, guerillas, prisoners in Turkey, and political activists in Europe are thus all subjected to frequently very similar rules, even though their social and political contexts are objectively very different. ${ }^{24}$

This system was no doubt initially developed among the guerrillas. 'Statutory' timetables were introduced, especially in winter which is better suited to training: an early rise, sometimes a bit of sport, four hours of theoretical lessons in the morning followed by three hours of military training in the afternoon, discussion of the day's training between $6 \mathrm{pm}$ and $8 \mathrm{pm}$, and finally free time before lights out at 9pm (Cigerli; Le Saout 2005: 147). A high degree of self-discipline is clearly expected, justified by the context of permanent danger: no complaints are allowed since 'it would sap the morale of the combatants,' sexual relations are forbidden as is the fact of being alone with one or several men for women, alcohol consumption is forbidden (as was smoking following a subsequent decision by the 'Leadership'), it is obligatory to take part in various activities, and desertion is of course forbidden (Flach 2003: 41, 128, 193, 57). Selfcriticism plays a considerable part in daily life and, as at the Academy, is carried out at various times and in various circumstances (primarily Tekmîl and the Assembly. Cf. Licht am Horizont: 183-184). Anja Flach, a German Internationalist who spent two years as a guerrilla, refers to it at least 22 times in her work (Flach 2003: 27, 42, 46, 81, 101, $110,120,136,141,163,169,177,186,190,192,199,225,232,237,247,262,272)$.

But PKK norms and rules have also been exported to Turkish prisons where prisoners, held in groups of 30 to 100 people of similar political tendency, are controlled by the organisation that is theoretically closest to them. 'Political' dormitories were introduced in the late 1970s so as to avoid clashes between radical left- and right-wing prisoners. This practice, which was continued and reinforced by political organisations in the 1980s, has resulted in a sort of contracting out of the prison order to organisations (Massicard 2002: 170-171). It is thus wholly possible to live according to the Academy rhythm when in prison, and to be subjected to a very similar discipline, which is in fact all the more stringent due to the fact of being imprisoned (the strict separation of men and women, for instance ${ }^{25}$ and the arbitrary nature of prison life (after having been tortured during custody, submitting to an organisation can seem to offer a guarantee against further harsh treatment).

Lastly, the wish to circumscribe the activists' lives is not limited to the Middle East, and the PKK has also sought to impose its life code and theory of the New Man on officials in Europe. The daily routine of an ERNK activist in Germany or France differs substantially of course from that of a prisoner or combatant. But, as in the Middle East, young recruits are obliged to follow two to three months of political training (there is no military training in Europe). Those who remain in European countries are subject to the same rules that apply in the Academy or to guerrillas, with alcohol and sexual relations being strictly forbidden, strict standards of dress applied, and self-critical reports presented to an 'interrogation committee' every two months and a report to the 'Leadership' every six months. The officials are constantly moved around and live with families (enabling mutual control of family and activist), and are not allowed to 
marry. Anyone wishing to leave the PKK may do so provided that they cease all political activity, and in the 1980s failure to respect this rule resulted on occasions in death (see Kutschera 2000 and especially Marcus 2007: 88-96).

\section{Forms of submission and ways of assessing it}

\section{Institutional configuration, roles, and domination}

It is now clear that the highly codified attitudes, behaviour, and roles result from the 'institutional configuration'26 at work in the PKK since 1986 - the way measures, knowledge, techniques, and activities are organised. The $3^{\text {rd }}$ Congress in 1986 did not simply set up an Academy in charge of educating activists in certain rules and norms, it also introduced, on the one hand, an internal promotion system based on loyalty to the leader and his values - independently of the political skills of the activists - and on the other hand placed Öcalan above everyone else in the position of just, infallible, and unassailable judge.

Initially conceived of as a party for and of the workers, the PKK started slanting its pronouncements towards the peasantry once the armed struggle had begun. The slogan of the $3^{\text {rd }}$ Congress shows this change, with the participants in Bekaa proclaiming that 'the peasants are in power.' Whilst this slogan was intended to draw the peasantry to the party's cause, since they were the large majority of the population in the Kurdish regions of Turkey, it also corresponded to a desire to promote peasants within the organisation (Çelik 2002: 112), and thereby sideline educated and/or experienced activists able to contest Öcalan's leadership. Many activists from peasant backgrounds, with no prior political skills, ${ }^{27}$ and unable to read or write, were rapidly promoted up through the party ranks (sometimes overnight), ${ }^{28}$ becoming members of the Central Committee thanks to their military exploits but above all their loyalty. Conversely, experienced commanders could be demoted after a self-criticism session lasting only a few minutes, then judged and condemned to death if found guilty of treason.

One consequence of this policy was the radical devaluing of intellectual and political skills within the party. The PKK leader himself frequently criticised activists who joined the party in the early 1990s 'on leaving universities and schools poisoned by the bourgeoisie' (Özcan 2006: 211), for 'true' intellectuals consisted uniquely in 'those who unconditionally praise Abdullah Öcalan' (quoted in Cigerli; Le Saout 2005: 132). From the $3^{\text {rd }}$ Congress on, the party's 'general secretariat' was replaced by the 'Leadership,' now separated into two, a 'strategic Leadership' and a 'tactical Leadership.' Öcalan is the de facto holder of the 'strategic Leadership' (but he rapidly had himself called simply 'Leadership,' Önderlik) and is in charge of all the key political directions, while the 'tactical Leadership' is entrusted to the members of the Central Committee who carry out the technical implementation of Öcalan's decisions. This way of operating takes all responsibility for implementing Öcalan's policies out of his own hands, and the members of the Central Committee always have to justify and explain any of their problems or failures (Çelik 2002: 109-111).

And thus truth, in the sense of pronouncements held to be true within the party (Foucault 1994: 112), has always and can only come from Öcalan, especially since activists very often understand nothing at all about his theory and so feel they are incompetent at expressing themselves. ${ }^{29}$ Öcalan - as 'Leadership,' 'President' (Serok or 
Rehber), 'guide,' and 'Sun' - has become one with the party's martyrs, who endow him with him legitimacy and sense of sacrifice. He has undisputed monopoly on the definition and interpretation of the truth (gerçeklik), of the 'reality' Kurds experience, as well as of the 'reality' of each activist. He alone 'is' the key to liberation - as opposed to just possessing it - and able to judge the level of investment required of each person if they are to become a true Man. The problem is that this ideal level of investment is necessarily out of reach - unless they sacrifice themselves as the 'emblematic' martyrs have done before them. It is thus not rare to hear PKK activists under-appreciate themselves, state that they have been lacking in faith (in the 'Leadership' and in themselves). The solution that Öcalan recommends is total submission to the truth as revealed by him, and compliance to the principles of his own life in the life of the activists - the disciplining of body and mind. But even those who follow his principles and his way of life may fall short and be deemed 'prostitutes' (fahişe), 'crooked' (alçak) and 'slavish' (Öcalan 1994: 505, Serxwebûn June 1998, Ballı 1991: 282 quoted in Özcan 2006: 208-209, 187).

This specific and lasting institutional configuration - which shifted further towards the person of Öcalan between 1986 and 1999 - was intended to result in the 'creation' of just two main 'roles' within the party - guide and disciple. Sidelined from any true political issues, activists were not required to acquire any specific know-how or practical knowledge other than integrating Öcalan's pronouncements and submitting to their leader's discipline. It is true that there are different institutional positions within the PKK - activist, takim, manga, bölük, and tabur commander (army units), sector and regional chief, and member of the Academy board, the European Central board, and the Central Committee. But all activists had to behave in the same way and incorporate a similar attitude system - and this independently of their positions within the hierarchy. ${ }^{30}$ Additionally, the insistence on destroying one's 'former personality' sought to suppress any tendency certain activists or categories of activist might have (men, women, people from cities, Europe, universities, a family that did not declare itself to be Kurdish, etc.) to not 'adhere to' the role assigned to them (Lagroye; François; Sawicki 2002: 144).

But nevertheless, as Goffman (1991) observes, individuals retain considerable autonomy in the role they have to adhere to, even in total institutions. Certain commanders used the aura Öcalan conferred on them to expand their role and establish their own power, something which was subsequently vigorously condemned by the movement. ${ }^{31}$ Equally, certain activists of peasant origin considered themselves to be intellectuals after writing a book or article (Çelik 2002: 112), before being rapidly called to order by their comrades (criticising), and required to carry out their own selfcriticism. More importantly, certain commanders in the mountains or in prison enjoyed a certain aura, such as Mehmet Can Yüce who was imprisoned from 1980 to 1999 and highly admired by some of the students who joined the party in the early 1990s, showing firstly that it is a lot harder to control and sanction 'transgressive ' $^{32}$ behaviour outside the total institution of the Mahsum Korkmaz Academy, and, secondly, that the Academy in fact considerably facilitated learning how to play the role of disciple. Finally and most significantly, the observations and interviews carried out in researching this article tend to show that there are almost as many ways of relating to the role one is called upon to 'adhere to' as there are individuals, even 
though certain factors tend to explain the attachment some feel for the institution, and certain situations can explain why others are dissatisfied and take their distance.

\section{Accepting, refusing, and negotiating one's role within the institution}

How do activists and sympathisers place their trust in the institution and entrust themselves to it (or the contrary)? How do they manage to adapt to disciplinary measures (or not)? It is of course impossible to assess the proportion of activists who overall accept their role, and what proportion tends not to. But whilst there is nothing to suggest that the training and education provided within the party are effective and necessarily fulfil their goals, ${ }^{33}$ the sheer number of disciplinary methods described above and the weight accorded to them suggest that it is impossible for an activist to remain outside the 'PKK system.' More specifically, each activist is explicitly called upon to position him - or herself, both publically and internally, in relation to their allotted role within the specific institutional configuration. There is of course no way of knowing whether the activists truly think what they say, just as activists have no way of adopting an alternative discourse to that of the hierarchy, as shown by initial interviews with pro-PKK associations in Europe carried out by the author, and initial observations of events.

After having met a large number of still active activists and sympathisers, it was decided to conduct interviews with several ex-activists and ex-sympathisers (sometimes doing the 'same' interview a few months later), so as to gather more considered, changing, and often more critical testimony. It was also decided to try to meet (ex-)activists and (ex-)sympathisers in a more neutral setting than the premises of pro-PKK associations (bars, the street, and the homes of the interviewees or interviewer), and this proved to be very fruitful (for instance, what still active activists had to say varied significantly with the setting). Without going over in detail the individual trajectories of the people encountered, ${ }^{34}$ it is worth providing a summary of the results of this study and trying to highlight a certain number of factors which can induce individuals to entrust themselves to the institution or on the other hand to question the role assigned to them.

First of all, are there any dispositions likely to encourage attachment to the PKK and submission to the ideal of commitment recommended by Öcalan? Interviews tended to show that Alevi Kurds experience greater difficulty in feeling wholly in tune with an organisation considered to be predominantly Sunni, and they often tend to feel their Kurdishness to be less natural and hence do not systematically link their fate to that of the PKK, unlike some Sunni activists. ${ }^{35}$ Yet if Hamit Bozarslan (1997) and Paul White (2000) are correct, the vast majority of those in Öcalan's party in the 1990s were Sunni Kurds, from the Kurdish-majority regions in Turkey, with little cultural and economic capital (peasants in villages or else having recently moved to towns). It would thus seem that primary socialisation in rural regions where Kurds were in the minority resulted in a lower predisposition to commitment and to entrusting oneself to the party, due especially to the history of these regions (which were less marked by repression and attempts to assimilate populations via schooling) as well as to the fact that the PKK only built up its presence here later on, meaning it was less frequently seen as a 'naturally' legitimate representative. 
'predisposition' hypothesis is highly schematic, though. Some of the Sunni Kurdish activists encountered were dissenters, whilst some of the Alevi Kurdish activists and sympathisers saw themselves as 'fanatics' at times (one of them for instance said that he thought of himself a leaf on the PKK tree, and another explained how she had cried when Öcalan was arrested). Equally, a certain number of students and individuals from wealthy backgrounds stated they had always felt 'in their right place' within the institution, and explained how they were seeking to give shape to a new form of humanity within themselves with great self-abnegation. They said, for example, that they felt guilty not to be doing enough for the cause, explaining that they were determined to 'leave their slavish mentality behind,' and that they were terrified of their inner enemies and disgusted by the 'plot' against Apo, etc.

41 In addition, the context in which they joined the party (out of necessity in prison, under the threat of a forced marriage, or else eagerly awaited for whatever reason) as well as time spent in various branches of the institution (the Mahsum Korkmaz Academy, the guerrilla, prison, etc.), would seem to attenuate or exacerbate the predispositions generated by primary socialisation and sometimes create a new disposition to accept one's role. All the interviews suggest that it is a lot easier to retain one's autonomy either in the big Turkish towns, where the party has sometimes found it hard to establish itself and where anonymity and insufficient means of communication preclude the homogenisation of activist practices and ethos, or in the Kurdish regions not controlled by the guerrillas, where the norms of traditional social networks can compete with those laid down by the party. Attending the Academy, however, and meeting Öcalan there tend to encourage attachment to the party and incite activists to adapt their personal trajectory to the expectations of the institution:

'At the Academy it was like the sun at midnight. [...] Öcalan was very knowledgeable and even said that when you're doing the washing-up, playing football, or eating, you need to think of the people. He was already adult when he was a child... For example, he said to us: "You don't need to be a man now. You need to think like a woman, for men only fight for power. But women love nature, trees, the mountains... That is how you can become a true patriot." [...] Öcalan has always found a solution. When he puts forward a new strategy, I am never surprised and I accept it.' (Interview with ex-combatant but still active activist, Germany, 2004) ${ }^{36}$

Whilst commitment and maintaining commitment are dynamic processes, the degree of attachment to the PKK and acceptance of partisan discipline change (sometimes radically) over time, in the light of the length of time and experiences as an activist, evolutions in the conflict with the Turkish State (cessation of fighting in 1998), and transformations within the organisation (the arrest of Öcalan in 1999). For example, it is not rare to hear certain ex-activists still close to the PKK say they used to have entire faith in Öcalan but that nowadays he has betrayed the cause, that there is no longer any place for their skills within the party, that the PKK is not what it used to be, etc. This dissatisfaction may be directly related to the role they were assigned within the organisation, as for one ex-combatant who was sent to join the guerrillas without receiving training at the Academy and who was initially an enthusiastic activist:

'The problem was that I didn't like their policies. I trusted them but... I had joined to help people. But it wasn't the case once you got there, you're not allowed to question Öcalan's orders. You're not free... If there were a Kurdish State it would be like the PKK... [...] You have to conduct your self-criticism and there's a meeting every week for that. Every 45 days there are regional meetings where we talked about life among the guerrillas. Some people stood up and criticised you and you

European Journal of Turkish Studies, Complete List 
defended yourself and did your own self-criticism. And they thought self-criticism

was good...' (Interview with an ex-combatant, Germany, 2003) way people fulfil their roles. In such a coercive system, it is a complex task to manage the gap in expectations between the individuals and the institution. Roles can be affected by people according themselves a certain leeway (taking a critical distance whilst displaying one's loyalty), arriving at partial and temporary cognitive accommodations (resignation combined with dissatisfaction), or outright rejections (which if they do not lead to desertion or suicide can be severely sanctioned). And the 'Leadership' is well aware of this, and regularly reminds people that 'behind every activist there lies hidden a prior traitor personality,' and places greater emphasis on daily practices almost (discipline has to be incorporated) than on its own pronouncements (which can remain fairly obscure).

doubt intermediary courses exist too, such as taking 'ratchet effects' (that restrain ability of processes to be reversed once a specific stage is reached) into account, strategies to delay decisions, or open states of depression, which oblige activists to work on themselves so as to cope with the present situation. The fact that the institution takes full charge of everyday activities also makes it possible not to find time to come up with alternative life scenarios and to stave off until later any decision that could affect one's trajectory. For most of the ex-activists interviewed, what enabled them to question their commitment to the party was an event that broke the institution's regulated organisation of time (being wounded in combat, having to quickly migrate to Europe, experiencing the arrest of Öcalan). Finally and no doubt most importantly, activists and sympathisers are far from resenting the 'entirety' of the PKK system. Most of the time, like any schoolchild or student, they like some lessons and some practices and find others uninteresting, unpalatable, or contrary even to what they still think - but this does not stop them from 'feeling in place' within the institution.

But it is also sometimes possible to negotiate one's role, providing one has sufficient resources. Having in-depth knowledge of the organisation, especially having brothers who were part of the first cohort of activists and who knew the founders, means one can 'speak the same language' as party officials and reach an agreement with them. Equally, coming from a wealthy family providing financial backing to the PKK makes it easier to sort out any areas of dispute with the organisation, especially when this is combined with 'sufficient' symbolic capital acquired during time with the PKK ("having already given a lot'):

'[In 1998 the PKK wanted to send this activist to join the guerrillas but she did not want to go]. They said to me "if you don't want to go to the mountains then you can't stay and work with us." Nobody said hello to me any more [...], they saw me as a traitor. And they tried to frighten me. [...] [In another town in Germany] my family had done a lot to help [the local pro-PKK association], and given perhaps $50,000 \mathrm{DM}$... And since they are a fairly important and powerful family they said to the PKK: "if something happens to D., we'll hold you responsible." And they left me in peace. A year later they got back in touch and came to see me. And I started going to the association once again. Some people understood my reasons, but others did not. They wanted to stop my friends from seeing me, but they stood up for me. In any case, I haven't been involved in politics [as I was before] after 1998.' (Interview with an ex-activist, still a PKK sympathiser, Germany, 2004)

European Journal of Turkish Studies, Complete List 
The interviews carried out thus show that various factors (predispositions, the fact of attending various branches of the institution, situational logics, economic resources, social capital, etc.) can interact (often in contradictory or seemingly illogical ways) to encourage or discourage activists from assuming roles within the PKK. It is thus possible that the disciplinary measures set up by the party may have had very different effects on different activists. Nevertheless, it was observed that those who have now withdrawn from the PKK, who are dissidents, or who are more critical, often still bear the marks of their time with the party (attitudes, lifestyles, vocabulary, principles, and so on) long after leaving the institution. Whilst it is not possible to come up with a quantitative assessment of the extent to which these measures worked, the evidence suggests that they had lasting effects on a large number of activists, influencing both their perception of the world and their post-activist daily life.

\section{Conclusion}

This study has shown how the PKK institution demands certain forms of practice and behaviour of its members, and presented the measures put in place to monitor, control, and sometimes punish deviant individuals who failed to conform to the theory of the New Man. There is also some indication that these measures work at least partially in different activist circles, and even with some sympathisers, who accept that their son or daughter go off to the mountains. It is of course extremely difficult to ascertain to what extent activists and sympathisers accept, integrate, and legitimate their role within the institution on the one hand, and understand, support, and legitimate practices and measures intended to homogenise these practices on the other. But it would seem that many individuals did accept the role assigned to them, and this to such an extent that they became 'agents' [Fr. actants] rather than actors, instruments at the service of a higher power rather than participants in a common cause.

At the same time, this article has shown that certain commanders have managed to create a certain degree of leeway for themselves and that sanctions have sometimes been taken against reluctant activists, showing that PKK members could also fail or refuse to conform to the institution's demands (due to their ethnic and religious identity for instance), or try to alter their role. It would seem that certain resources predating their joining the PKK (their social, cultural, and economic capital) or else acquired within the movement (symbolic capital) sometimes enable activists to negotiate with the institution, even after having attended certain highly coercive components of the institution (the Mahsum Korkmaz Academy, the guerrilla, or prison). These observations, showing that the subservience of individuals to the institution and its leader can vary, help explain why it can seem inappropriate to view the PKK via preconceived categories. Analysing the relationship between Öcalan's organisation and its activists is in fact a matter of analysing the encounter between an institution and a multitude of individuals with sometimes very different activist experiences.

49 Lastly, this article has shown that the institutional configuration of the PKK seems to have been very stable since 1986. However, the arrest of Öcalan in 1999 amounted to an unprecedented institutional crisis, bringing with it the risk that the party would rapidly disintegrate as the roles set up within the PKK were now null and void. This is no doubt why the Turkish army authorised Öcalan to send 'instructions' to his 
movement via his lawyers, and what led the commanders, after a few weeks of hesitation, to re-elect Öcalan as party leader. Since then loyalty to Apo has primarily involved mental and physical discipline, seen as the only means of carrying forward the 'combat for civilisation.' The 'regime of truth' (Lagroye 2006: 142) at work within the PKK, or 'regime of proof' as Paul Veyne (1983) calls it, would thus seem to have been preserved, at least for the large majority of activists and sympathisers - if Öcalan still believes in these truths, then that means they are still true.

\section{BIBLIOGRAPHY}

Arbeitskreis Internationalismus Bonn, Initiative Internationale Solidarität Bremen, Freunde und Freundinnen des kurdischen Volkes Gießen et Kurdistan Solidarität Nürnberg (1991) Serfirazkin. Wir werden siegen! Berichte und Interviews zum kurdischen Befreiungskampf, Osnabrück, Montageverlag.

Aydın, Ertan (2003) The Peculiarities of Turkish Revolutionary Ideology in the 1930s: The Ülkü Version of Kemalism, 1933-1936, Ankara, Doctoral Dissertation, Bilkent University.

Ballı, Rıfat (1991) Kürt Dosyası [the Kurdish issue], İstanbul, Cem Yayınları.

Batard-Bonucci Marie-Anne; Milza, Pierre (eds.) (2004) L'Homme nouveau dans l'Europe fasciste (1922-1945), Fayard.

Becker, Howard S. (1985) Outsiders. Etude de sociologie de la déviance, Paris, Métailié.

'Bei den Kurden hat eine erstaunliche Revolution stattgefunden. Interview mit dem Mitglied des PKK-Präsidialrates Ali Haydar Kaytan' (2001), Kurdistan Report, 101 (first published in Turkish in Özgür Politika, 29 April 2001).

Bozarslan, Hamit (2004) Violence in the Middle-East : From Political Struggle to Self-Sacrifice, Princeton, Markus Wiener Publishers, 2004.

Bozarslan, Hamit (2001) 'Quelques remarques sur le discours historiographique kurde en Turquie : 1919-1980’, Asien Afrika Lateinamerika, vol. 49, pp. 47-71.

Bozarslan, Hamit (1997) La question kurde. Etats et minorités au Moyen-Orient, Paris, Presses de Science Po.

‘Cemşid Bender’le Kürt tarihi üzerine...' [With Cemşid Bender on Kurdish history] (1995) Özgür Politika, 26 September, p. 9.

Chaliand, Gérard (1991) 'Franz Fanon à l'épreuve du temps', in Fanon, Franz, Les Damnés de la terre, Paris, Gallimard, pp. 7-36.

Cigerli, Sabri; Le Saout, Didier (2005) Öcalan et le PKK. Les mutations de la question kurde, Paris, Maisonneuve \& Larose.

Copeaux, Etienne (1997) Espaces et temps de la nation turque. Analyse d'une historiographie nationaliste, 1931-1993, Paris, CNRS Editions. 
Çelik, Selahattin (2002) Den Berg Ararat versetzen. Die politischen, militarischen, ökonomischen und gesellschaftlichen Dimensionen des aktuellen kurdischen Austand, Frankfurt am Main, Zambon Verlag (first published in Turkish in 2000 under the title Ağrı dağını taşımak (Çağdaş kürt halk direniş̧i, siyası, askeri, ekonomik ve toplumsal sonuçları) [Carrying Mount Ararat. The political, military, economic, and social dimensions of the current rebellion of the Kurdish people].

Çürükkaya, Selim (1997) PKK. Die Diktatur des Abdullah Öcalan, Frankfurt am Main, Fischer Verlag (first published in Turkish under the title Apo'nun Ayetleri [The verses of Apo], place of publication unknown (Switzerland), 14 Temmuz Yayınları, date of publication unknown).

Della Porta, Donatella (1995) Social Movement, Political Violence and the State. A Comparative Analysis of Italy and Germany, Cambridge, Cambridge University Press.

Dorronsoro, Gilles; Grojean, Olivier (2004) 'Engagement militant et phénomènes de radicalisation chez les Kurdes de Turquie', European Journal of Turkish Studies, URL: http://ejts.revues.org/198 (accessed 12 May 2014).

Ducoulombier, Romain (2007) Régénérer le socialisme. Aux origines du communisme en France (1905-1925), Paris, Doctoral thesis, IEP de Paris, Paris.

Elias, Norbert (1978) What is sociology?, London, Hutchinson.

Flach, Anja (2003) Jiyanekê din - ein anderes Leben. Zwei Jahre bei der kurdischen Frauenarmee, Cologne, Mezopotamien Verlag.

Foucault, Michel (1994) Dits et écrits, Vol. 2, Paris, Gallimard.

Garner, Roberta A.; Zald, Mayer N. (1987) ‘The Political Economy of Social Movement Sectors', in McCarthy, John D.; Zald, Mayer N. (eds.), Social Movement in an Organizational Society. Collected Essays, New Brunswick, Transaction Book, pp. 293-318.

Goffman, Erving (1991) Asylums: Essays on the Social Situation of Mental Patients and Other Inmates, New York, Penguin Books.

Grojean, Olivier (2013a) 'Théories et construction des rapports de genre dans la guérilla kurde de Turquie', Critique internationale, 60, pp. 21-35.

Grojean, Olivier (2013b) ‘Comment gérer une crise politique interne ? Façonnage organisationnel du militantisme, maintien de l'engagement et trajectoires de défection', Politix, 102, pp. 63-87.

Grojean, Olivier (2008) 'La cause kurde, de la Turquie vers l'Europe. Contribution à une sociologie de la transnationalisation des mobilisations', unpubl. doctoral thesis, Paris, École des Hautes Études en Sciences Sociales.

Grojean, Olivier (2006) 'Investissement militant et violence contre soi au sein du parti des Travailleurs du Kurdistan', Cultures \& Conflits, 63, pp. 101-112.

Grojean, Olivier; Küçük, Bülent (2006) 'Le PKK après la capture d'Öcalan. Phénomène charismatique et mythes politiques au sein du mouvement kurde', Etudes kurdes, 8, pp. 63-84.

Hirschler, Konrad (2002) 'Diskursive Raüme in der PKK. Eine Studie zur kurdischen Geschichtschreibung', Kurdische Studien, 2(1), pp. 63-79.

İrem, Nazım (2002) 'Turkish Conservative Modernism: Birth of a Nationalist Quest for Cultural Renewal', International Journal of Middle East Studies, 34(1), pp. 87-112.

Koç, Serpil (1993a) 'Die Frauenfrage ist auch eine Männerfrage', Kurdistan Report, 61, pp. 38-42. Koç, Serpil (1993b) ‘Die Frauenfrage ist auch eine Männerfrage (Teil 2)’, Kurdistan Report, 63, pp. 37-39. 
Kriegel, Annie (1972) Les grands procès dans les systèmes communistes, Paris, Gallimard.

Kutschera, Chris (2000) 'Révélations sur le système Öcalan', Confluences Méditerranée, 34, pp. 113-117.

Lagroye, Jacques (2006) La vérité dans l'Eglise catholique. Contestation et restauration d'un régime d'autorité, Paris, Belin.

Lagroye, Jacques (1997) ‘On ne subit pas son rôle. Entretien avec Jacques Lagroye’, Politix, 10(38), pp. 7-17.

Lagroye, Jacques; François, Bastien; Sawicki, Frédéric (2002) Sociologie politique, Paris, Presses de Sciences Po \& Dalloz.

Lagroye, Jacques; Siméant, Johanna (2003) ‘Gouvernement des humains et légitimation des institutions', in Favre, Pierre (ed.), Etre gouverné - Mélanges en l'honneur de Jean Leca, Paris, Presses de Sciences Po, pp. 53-71.

Licht am Horizont. Annäherungen an die PKK, place of publication unknown (Germany), $2^{\text {nd }}$ ed., date of publication unknown (first edition 1995 or 1996).

Marcus, Aliza (2007) Blood and Belief. The PKK and the Kurdish Fight for Independence, New York \& London, New York University Press.

Massicard, Elise (2002) 'La réforme carcérale en Turquie. Du bon usage de la norme européenne', Critique internationale, 16, pp. 169-181.

O’Shea, Maria T. (1994) ‘Between the Map and the Reality. Some Fundamental Myths of Kurdish Nationalism', Peuples méditerranéens, 68-69, pp. 165-184.

Öcalan, Abdullah (2003) Gilgameschs Erben. Von Sumer zur demokratischen Zivilisation, Band 2, Bremen, Atlantik Verlag (first published in Turkish under the title Sümer Rahip Devletinden Halk Cumhuriyetine Doğru [From the Sümer Ecclesiastical State to the Popular Republican State], İstanbul, Mem Yayınları, vol. 2, $2^{\text {nd }}$ edition, 2001.

Öcalan, Abdullah (1997a) 'Wie leben? (Teil V) Erobert das Leben! Aus dem Buch "Wie leben" von Abdullah Öcalan' [excerpts from Nasıl Yaşamalı? (How is one to live?), Vol. I \& II, Cologne, Weşanen Serxwebûn, 1995 and 1996], Kurdistan Report, 86, pp. 34-38.

Öcalan, Abdullah (1997b) ‘Wie leben? (Teil IV) Über die Konfrontation mit Schwierigkeiten und Freiheiten' [excerpts from Nasıl Yaşamalı? (How is one to live?), Vol. I \& II, Cologne, Weşanen Serxwebûn, 1995 and 1996], Kurdistan Report, 85, pp. 41-45.

Öcalan, Abdullah (1994) Halk Savaşında Militan Kişilik [The activist personality in popular war], Cologne, Weşanên Serxwebûn.

Öcalan, Abdullah (1993) ‘Es gibt nicht nur eine Frauenfrage, sondern auch eine Männerfrage. Über die Rolle der Familie (Teil 3), aus den Analysen des Generalsekretärs der PKK, Abdullah Öcalan, vom Dezember 1987', Kurdistan Report, 58, pp. 22-26.

Öcalan, Abdullah (1992) Kadın ve aile Sorunu [The issue of woman and family], İstanbul, Melsa Yayınları.

Öcalan, Abdullah (1986) Seçme Yazılar [Selected writings], Vol. II, Cologne, Weşanen Serxwebûn.

Öcalan, Abdullah (1983) Kürdistan'da Kişilik Sorunu [The question of personality in Kurdistan], place of publication unknown, publisher unknown.

Özcan, Ali K. (2006) Turkey's Kurds. A Theoritical Analysis of the PKK and Abdullah Öcalan, New York, Routledge. 
Ozouf, Mona (1989) L’homme régénéré. Essais sur la Révolution française, Paris, Gallimard.

Pennetier, Claude; Pudal, Bernard (eds.) (2002) Autobiographies, autocritiques, aveux dans le monde communiste, Paris, Belin.

PKK (1986) Der Weg der Revolution Kurdistans (Manifest), Weşanen Serxwebûn/Agri Verlag, Köln (first published in Turkish under the title Kurdistan Devrimin Yolu - Manifesto in 1978).

Sartre, Jean-Paul (1991) Preface to Fanon, Franz, Les Damnés de la terre, Paris, Gallimard, pp. 37-61. Solina, Carla (1997) Der Weg in die Berge. Eine Frau bei der kurdischen Befreiungsbewegung, Hamburg, Nautilus.

Strohmeier, Martin (2003) Crucial Images in the Presentation of a Kurdish National Identity. Heroes and Patriots, Traitors and Foes, Leiden, Brill.

Üçlü, M. S. (1996) ‘Kürdistan'da Yeni İnsan' [The New Man in Kurdistan], Serxwebûn, March, p. 21. Veyne, Paul (1983) Les Grecs ont-ils cru à leurs mythes?, Paris, Seuil.

White, Paul (2000) Primitive Rebels or Revolutionary Modernizers? The Kurdish National Movement in Turkey, London, Zed Books.

\section{NOTES}

1. One may also trace the intellectual origins of the "New Man", however, to early Christian writings.

2. The only study in French (of which the author is aware) that seeks to analyse the theory of the New Man in a Marxist party prior to the October Revolution is that by Ducoulombier (Ducoulombier 2007).

3. This observation does not hold to quite the same extent, however, in studies of the "communist world".

4. A repertoire of collective action is defined by Charles Tilly as the range of actions used by a movement in its interactions with third parties. It is true that some examples show that certain ideas can easily be "put into practice" (such as Gandhi's repertoire of non-violence), but analysis always reveals a certain shortfall between theory and practice due to constraints arising from any situation in which interaction takes place.

5. Their environment of course still influences radical organisations: "opposing" often also means "maintaining contact with", especially when what the organisation is trying to bring about is a transformation of this environment (ideological imitation, for example). Putting into practice a theory intended strictly for internal use (the desire to transform activists) would appear to be less affected by the relationship to the external environment when there are substantial symbolic and material frontiers cutting across the social organisation (clandestine status, camps abroad or in the mountains, being obliged to choose one's "camp", etc.). See Garner; Zald 1987 on the distinction between exclusive movements (requiring considerable activist involvement) and inclusive movements (where activist involvement is far less valued) on the one hand and, on the other, organisations seeking primarily to change activists or else more widely bring about social change.

6. The PKK, led by Abdullah Öcalan since 1978, has been engaged in a guerrilla war against the Turkish state since 1984. The leader of the PKK was arrested in 1999 but still "advises" his organisation from prison. A recent assessment by the Chief of the General Staff, illker Başbuğ, puts the number of deaths from the conflict at 44,000 (Hürriyet, 16/09/2008). 
7. See for instance Bozarslan 2004, Grojean 2006, and Grojean 2008: 581-640 for discussion of this issue.

8. Any hypothesis as to the nature of the PKK organisation (" terrorist", "sectarian", "total", "totalitarian", or else on the contrary "national liberation movement" or "freedom fighters organisation") runs the risk of becoming self-confirming as the argument unfolds, and thus legitimating the frameworks through which the various protagonists perceive their own actions. 9. In the PKK, activists - clandestine members of the party involved on a full-time basis in its political or military wing - are also officials (there are only about 150 in Germany and twenty or so in France for instance, cf. Cigerli; Le Saout 2005: 153), whereas sympathisers, who are not members of the clandestine organisation - though some are involved full-time in legal, pro-PKK associations (in which case they live in the same way as activists) - can be simply members of these associations in Europe (it is estimated that there are about 11,000 in this situation in Germany today) or else militiamen in Turkey (illegally helping the guerrillas), or else may only provide more indirect support (such as financial support or only taking part periodically in the activity of legal associations). In principle, European activists are only associated with the political branch of the party, but a certain number of former combatants, some of whom are still active, others not, also live in Europe. The author met over one hundred people belonging or having belonged to these categories, and carried out more in-depth biographical interviews with 38 of them.

10. It might here seem that nothing can replace observing activist practice in situ. But apart from the fact that such an approach within a clandestine organisation at war might actually pose more methodological problems than it solves, such a method could well lead to the over-hasty conclusion that theory and practice coincide perfectly, since coercive measures and mutual surveillance within the institution tend to lead people to "adhere' more closely to their role in the presence of a researcher.

11. Some people claim that the Kurds were the first people to have mastered horse breeding, and that they invented mathematics and the telescope. Cf. "Cemşid Bender'le Kürt tarihi üzerine..." [With Cemşid Bender on Kurdish history], 1995, pp. 9, quoted in Hirschler 2002: 73-74.

12. The German edition only includes the second and third part of the Turkish edition, as stated in its Preface.

13. A similar phenomenon occurred in Germany and Italy in the 1970s. Cf. Della Porta 1995: 85.

14. The Çözümlemeler started in 1986, when the Academy was founded. They are long speeches providing the basis for activist training and published as works up to six years after being written.

15. It is true that there are conflicting interpretations and even different "trends" within the PKK movement, but racial and biological concepts of identity dominate nonetheless. Cf. Hirschler 2002: 75 .

16. "There is no doubt that the Kurds have to some extent been fighting themselves, in an internal war, a war over people's minds". Cf. "Bei den Kurden hat eine erstaunliche Revolution stattgefunden...", 2001.

17. In the same way as the Turkish people, who stand out for their masculinity, have colonised and enslaved the Kurdish people, Kurdish men have colonised and enslaved Kurdish women. Since the "traditional" masculine personality traits were associated with domination, violence, superiority, and arrogance, male PKK activists needed to free themselves from this sort of way of living and behaving and adopt the personality of the New Man, whose characteristics - inspired by those of the "free" woman - are peace, communion with nature, culture, "sociality", and a sense of patriotic duty. Since personal responsibility and perfection are the only ways to reach Öcalan, activist men and women are to leave their gender behind them together with its harmful attributes so as to better follow Öcalan - who wishes to become the leader of a "party of [free] women" - and reach a truly human status. See Koç 1993a and 1993b, Öcalan 1993 and more generally Öcalan 1992. 
18. Since 1999, the "struggle for democratic civilisation" has conjoined socialist and democratic ideology - rebaptised "Apoism' (in reference to Öcalan's nickname, Apo, that is "Uncle") - cultural demands (not nationalist demands) and the theory of the New Man. Cf. Öcalan 2003.

19. In 1991 lessons included the history of Kurdistan, resistance, the party, and MarxismLeninism, knowing the enemy, special war methods, and techniques for political unrest and mobilisation (cf. Arbeitskreis Internationalismus Bonn et al., "Alltag in der Mahsum Korkmaz Akademie" 1991: 7). In 1995 the syllabus was expanded to include philosophy lessons (both "world" and party philosophy), and lessons in art, culture, religion, education, woman's role in the family, and behaviour (Solina 1997: 326).

20. "12 September" personality refers to the behaviour and way of life of certain activists who grew up after the 1980 coup. They are accused of being westernised, having a vastly diminished sense of responsibility, and being very individualistic. "Convict' personality corresponds to that of activists imprisoned after 12 September, and involves over-familiarity with the Leadership, a lack of respect for Öcalan, and a tendency to resist discipline. Cf. Arbeitskreis Internationalismus Bonn et al., "Gerichtsverhandlung in der Mahsum Korkmaz Akademie", 1991: 40-41 and Çürükkaya 1997: 79, 85, 91.

21. Stolen glances towards a friend of the opposite sex may be considered to be signs of desire. Cf. Çürükkaya 1997: 124.

22. Arbeitskreis Internationalismus Bonn et al. 1991: 40-41. Two "12 September" repeat offenders are described in this article, a man who refused to follow the military part of training and a former radical left-wing activist suspected of being an "agent" sent by the Turkish State.

23. Charges were brought against Çürükkaya himself after he had organised the elections to the Kurdish parliament in exile in Europe along lines that displeased the "Leadership" (1992). He subsequently fled and has since lived in hiding in Germany.

24. The measures studied here are intended primarily for members of the organisation, but the PKK has also sought to apply a certain number of rules to its sympathisers and more generally the population, although this is the case only in places where there was the will to do so and the capability (Kurdish regions in Syria and Iraq, "liberated zones" in Turkey, and in Europe via numerous legal Kurdish associations).

25. As there tend to be fewer women, their groups are sometimes controlled by several organisations (the PKK, TKP-ML, and DHKP-C for example).

26. The notion of configuration is taken from Elias (Elias 1978) and "conveys the plasticity of the relationships between various analysable processes, and so makes it easier to understand changes which though not modifying the overall architecture can nevertheless have an effect on its signification" (Lagroye 2006: 132).

27. "Trigger events" (the assassination of a member of the family, the imprisonment of a father, etc.) were often their sole form of political experience and many were purely out for vengeance.

28. Interview with a former PKK guerrilla, Germany, June 2004.

29. The guerrillas often find it extremely hard to understand the theoretical lessons due to their low level of cultural capital and also to language problems (some do not speak Turkish, the principal working language in the party).

30. See Lagroye 1997, for discussion of the difference between institutional "positions" and "roles".

31. The main commander targeted by such criticism was şemdin Sakık (Zeki), who was accused of having behaved like an "agha" and whose name was used to designate a category of practices to be avoided. The names of other commanders were used for other categories of deviant behaviour. Cf. Flach 2003: 100, 117, 134, 153-154, 169, 182.

32. "Transgressive", but not "deviant" (in the sense used by Becker 1985): until 1998, Mehmet Can Yüce pledged full allegiance to Öcalan. 
33. The possibility of true self-fulfilment within the institution independently of any coercion should not be excluded either (cf. Lagroye; Siméant 2003).

34. The numerous itineraries of the activists and sympathisers interviewed is not developed here due to lack of space. For more details, see Grojean 2103b.

35. This is less the case for Alevi Kurds who migrated to Europe before joining the party.

36. But Öcalan's charismatic domination is felt far beyond Germany. Amongst those interviewed, most of the activists and many of the sympathisers who are still committed see him as an extraordinary being, with boundless intelligence ("he revolutionised world philosophy"), outstanding political far-sightedness ("he was the only one to have anticipated the coup in 1980"), an enormous capacity for work ("he only sleeps five hours a night and can talk for eight hours non-stop"), with unrivalled love and understanding for his activists ("he never forgets the face of someone he has spoken to"), of unique generosity and humanity ("the greatest pacifist in the world"), etc. (Interviews with PKK activists, former activists and sympathisers, Germany and France, 2001-2005).

\section{ABSTRACTS}

Scholars have analyzed theories of the 'New Man' primarily as an ideological component of totalitarian systems. Based on the study of the Kurdistan Workers' Party (PKK), the most important organization of the Kurdish movement in Turkey, this article goes beyond the frame of state ideologies to examine the relationships between theory and practice, and to evaluate the concrete effects of the New Man doctrine on PKK activists. The article examines political discourses within the PKK to help to understand how, beyond Marxism and nationalism, a specific construction of the New Man was institutionalized in the party. The party used a number of disciplinary mechanisms to do this; in particular, self-criticism played an important role in all branches of the organization. Evaluating the efficacy of these measures is difficult, but the article suggests that activists' personal biographies and social trajectories help explain how and why some militants were (or were not) able to conform to the PKK ideal.

Les chercheurs ont surtout analysé les théories de l'« Homme nouveau » en tant que composante idéologique des systèmes totalitaires. Fondée sur l'étude du Parti des Travailleurs du Kurdistan (PKK), la plus importante organisation du mouvement kurde de Turquie, cet article dépasse le cadre des idéologies d'Etat pour analyser les relations entre théories et pratiques, et pour évaluer les effets concrets de la doctrine de l'Homme nouveau sur les activistes du PKK. Cet article examine donc les discours politiques au sein du PKK afin de comprendre comment, au delà du marxisme et du nationalisme, s'est institutionnalisée une construction spécifique de l'Homme nouveau au sein de l'organisation. A cette fin, le parti a utilisé un certain nombre de dispositifs disciplinaires : l'autocritique a notamment joué un rôle très important dans toutes les branches de l'organisation. Evaluer l'efficacité de ces dispositifs est difficile, mais l'article suggère que l'étude des trajectoires biographiques des individus engagés permet de mieux comprendre pourquoi et surtout comment certains militants ont pu (ou pas) se conformer aux idéaux développés par le PKK. 
INDEX

Keywords: militancy, theory/practice, New Man, PKK, discipline

Mots-clés: militantisme, théorie/pratique, Homme nouveau, PKK, discipline

\section{AUTHORS}

\section{OLIVIER GROJEAN}

Aix-Marseille University 